\title{
Mapping the Hg-impacted area in the Paglia River Basin (Mt. Amiata Mining District - Italy)
}

\author{
S.FORNASARO ${ }^{1 *}$, G. MORELLI ${ }^{2}$, P. COSTAGLIOLA ${ }^{1}$, V. RIMONDI ${ }^{1}$, P. LATTANZI ${ }^{2}$, C. FAGOTTI ${ }^{3}$
}

${ }^{1}$ Dipartimento di Scienze della Terra, Università degli

Studi di Firenze, Firenze, Italy (*correspondence:

silvia.fornasaro@unifi.it )

${ }^{2}$ Consiglio Nazionale delle Ricerche-IGG, Firenze, Italy

${ }^{3}$ ARPAT-Area Vasta Sud, Siena, Italy

Mercury $(\mathrm{Hg})$ is recognized as a global pollutant and a potentially harmful element (PHE) to human health and to the environment.

The Mt. Amiata Hg district, Southern Tuscany (Italy), was the third largest worldwide site for $\mathrm{Hg}$ production (1847-1982). It is part of the large circumMediterranean $\mathrm{Hg}$ belt, which hosts $65 \%$ of the world's cinnabar deposits.

As a consequence of this large $\mathrm{Hg}$ anomaly and extensive mining activity, the Mt. Amiata region is a $\mathrm{Hg}$ source of remarkable environmental concern at the local (Paglia River), regional (Tiber River), and Mediterranean scales. Meteoric events and weathering of the abandoned mining wastes facilitated the transport of $\mathrm{Hg}$ associated to fluvial particulate, principally in the environments of the Paglia River and its tributaries downstream of the mines.

Concentrations of $\mathrm{Hg}$ in stream sediments $(>0.2-$ $1900 \mathrm{mg} / \mathrm{kg}$ ), suspended particulate sediments (2-290 $\mathrm{mg} / \mathrm{kg})$ and soils $(<0.2-120 \mathrm{mg} / \mathrm{kg})$ from alluvial terraces along the Paglia River and its main tributaries (Stridolone and Siele Creek) are mostly above the legal limit $(1 \mathrm{mg} / \mathrm{kg})$ defined by the Italian law. Thus, using GIS-based software, a "Hg impacted" area was defined along the course of the Paglia River, including sediments and soils with $\mathrm{Hg}>1 \mathrm{mg} / \mathrm{kg}$ along transects longitudinal to the river course.

The extent of the contaminated area does not allow any environmental remediation. The identification of the "impacted area" can be a useful tool for the local communities and environmental national agencies when planning works involving the remobilization of sediments, to prevent the dispersal of old deposited contaminants, as well as to prevent $\mathrm{Hg}$ exposure pathways to humans. 